\title{
Estimates for digestible threonine: lysine for 21 - 35-day-old female meat-type quails
}

\author{
Estimativa das relações treonina: lisina digestivel para codornas de corte fêmeas no \\ período de 21 a 35 dias
}

CASTRO, Mariana Resende de ${ }^{1}$ https://orcid.org/0000-0002-6631-6417

PINHEIRO, Sandra Regina Freitas ${ }^{1}$ https://orcid.org/0000-0001-8509-8497

DALÓLIO, Felipe Santos ${ }^{1}$

https://orcid.org/0000-0001-7669-6364

LIMA, Héder José D’ Ávila https://orcid.org/0000-0002-8360-8227
ABREU, Luíza Rodrigues Alves ${ }^{1}$
https://orcid.org/0000-0001-9926-6359

OLIVEIRA, Renata Gomes de ${ }^{1}$

https://orcid.org/0000-0001-8070-0768

MOTA, Lúcio Flávio Macedo ${ }^{1}$

https://orcid.org/0000-0001-9983-1784

CARVALHO, Débora Cristine de Oliveira ${ }^{3}$ https://orcid.org/0000-0002-6095-7969

${ }^{1}$ Universidade Federal dos Vales do Jequitinhonha e Mucuri, Programa de Pós-Graduação em Zootecnia, Diamantina, Minas Gerais, Brasil.

${ }^{2}$ Universidade Federal de Mato Grosso, Faculdade de Agronomia, Medicina Veterinária e Zootecnia, Cuiabá, Mato Grosso, Brasil.

${ }^{3}$ Universidade Federal do Vale do São Francisco, Petrolina, Pernambuco, Brasil.

* Corresponding author: sandrafreitaspinheiro@gmail.com

\section{ABSTRACT}

Two assays were performed to estimate digestible threonine-lysine (Threo-Lys) ratio for female meat-type quails between 21 and 28 days old and between 28 and 35 days old. Experimental design was totally randomized. The first assay comprised 440 quails distributed into 5 treatments, 8 replications and 11 fowls per cage. The second assay comprised 280 quails distributed into 5 treatments, 8 replications and 7 fowls per cage. Five digestible Threo: Lys ratios were evaluated $(0.66,0.71,0.76,0.81$ and 0.86$)$. Performance, carcass and cut yield, chemical composition of carcass and nitrogen balance were evaluated. There was an improvement $(\mathrm{P}<0.05)$ in feed conversion and increase in feed intake due to ratios of digestible Threo: Lys between 21 and 28 and between 29 and 35 days olds, respectively. At 35 days old, there was a better $(\mathrm{P}<0.05)$ carcass yield and a negative nitrogen balance for Threo: Lys analyzed. A ratio of 0.86 may be recommended for digestible Threo: Lys as the best for feed conversion and carcass yield for female meat-type quails between 21 and 28 and between 28 and 35 days.

Keywords: essential amino acids, ideal protein, limiting amino acid, mucin, productive performance. 


\section{RESUMO}

Foram realizados dois experimentos com o objetivo de estimar as relações treonina: lisina (Treo: Lis) digestíveis para codornas de corte fêmeas durante os períodos de 21 a 28 e 28 a 35 dias de idade. $\mathrm{O}$ delineamento experimental foi o inteiramente casualizado. No primeiro experimento foram utilizadas 440 codornas distribuídas em cinco tratamentos, oito repetições e 11 aves por gaiola. Para o segundo experimento utilizou-se 280 codornas distribuídas em cinco tratamentos, oito repetições e sete aves por gaiola. Foram avaliadas cinco relações Treo: Lis digestíveis $(0,66 ; 0,71 ; 0,76 ; 0,81$ e 0,86$)$. Avaliou-se o desempenho, o rendimento de carcaça e de cortes, a composição química da carcaça e o balanço de nitrogênio. Observou-se melhora $(\mathrm{P}<0,05)$ da conversão alimentar e aumento do consumo de ração devido às relações Treo: Lis digestíveis, nos períodos de 21 a 28 e 29 a 35 dias de idade, respectivamente. Aos 35 dias observou-se melhor $(\mathrm{P}<0,05)$ rendimento de carcaça e balanço de nitrogênio negativo com Treo: Lis avaliadas. Recomenda-se a relação de Treo: Lis digestível de 0,86 como o ótimo para a conversão alimentar e o rendimento de carcaça das codornas de corte fêmeas nos períodos de 21 a 28 e 28 a 35 dias.

Palavras-chave: aminoácidos essenciais, aminoácido limitante, desempenho produtivo, mucina, proteína ideal.

\section{INTRODUCTION}

Since fowl diets have been formulated for many years particularly with crude protein levels and total amino acids, lack of balance between essential amino acids has been a constant, with high energy expenditure to catabolize and excrete the resulting products and, consequently, increase in environmental pollution. The concept of the ideal protein has been raised in which all amino acids would be provided, without either excesses or deficiency based on digestible lysine rates.

Threonine is the third limiting amino acid in diets for fowls formulated with corn and soybean meal. According to Corzo et al. (2007), this type of amino acid may become the first limiting factor in fowl diets since currently methionine + cysteine and lysine demands are already being complied with when diets are formulated with corn and soybean meal and supplemented with industrial amino acids. Threonine has several functions in the organism, such as, relevant glycine and serine precursor, glycine saver, optimization of immune response for immunoglobulin synthesis, for gastro-intestine health by mucin synthesis, formation of uric acid, pancreatic enzymatic re-synthesis, protein formation, collagen and elastin synthesis (KIDD \& KERR, 1997; DEBNATH et al., 2019).

Research results show that nutritional requirements of a particular amino acid may vary according to genetic capacity, gender, development stage, room temperature, crude protein rate of diet and quality and balancing of ingredients in the formula used (EBLING et al., 2013).

In meat-type quail breeding, males and females are laid down for the commercialization of their carcass. According to Silva et al. (2006), females of the European strain are 10\% heavier than 6 - 8-week-old males and, consequently, should be killed at a younger age to avoid greater losses due 
to removal of reproduction organs. Further, Silva et al. (2012) reported that European quail's requirements are different from Japanese ones and, thus, research has to be undertaken to assess nutritional needs for female European quails.

Current paper estimates digestible Threo-Lys ratio in diets for female meattype quails aged 21 and 28 days old and 28 and 35 days old.

\section{MATERIALS AND METHODS}

Two assays were conducted in the Monogastric Animal Research Laboratory of the Department of Animal Science, Universidade Federal dos Vales do Jequitinhonha e Mucuri. Protocol was approved by the Committee for Ethics in the usage of Animals (CEUA) $n$. $032 / 2012$.

The first assay comprised 440 female meat-type quails (Coturnix coturnix), strain LF1, 21 to 28 days old, initially weighing $156 \mathrm{gr}$, distributed in a totally randomized design, with 5 treatments, 8 replications and 11 fowls per cage. The second assay comprised 280 female meat-type quails (Coturnix coturnix), strain LF1, 28 to 35 days old, initially weighing $215 \mathrm{gr}$, distributed in a totally randomized design, with 5 treatments, 8 replications and 7 fowls per cage. Quails were retrieved from hatching house maintained by the Program for Genetic Improvement of Quails of the UFVJM and vaccinated against Marek disease. They were housed in a brick shed, with cages, between the $1^{\text {st }}$ and $20^{\text {th }}$ day of age, sexed on the $18^{\text {th }}$ day; females were separated and removed to experimental shed at age 21 to 28 days old, according to the evaluated experimental period.
They received diets till the $20^{\text {th }}$ and $27^{\text {th }}$ days of age following requirements by Silva e Costa (2009), except for ratio methionine + cysteine, according to Castro (2014). Quails of the second assay were not the same as those used in the first assay.

Experimental installations included a brick shed with galvanized wire cages $(60 \times 60 \times 35 \mathrm{~cm})$. They featured three sets, each set with 4-layer cages. Each cage had a pressure drinking drip and a feeding trough, with water and feed ad libitum. Room temperature was measured at 8:00h and 15:00h by digital thermometers in each set.

A diet based on corn and soybean meal was formulated comprising $0.61 \%$ digestible threonine equivalent to Threo: Lys ratio 0.66. Diet was supplemented with 5 L-threonine (98.5\%) levels replacing glutamic acid in protein equivalent and starch in energy equivalent, corresponding to digestible Threo-Lys ratios $0.66,0.71,0.76,0.81$ and 0.86. All diets were iso-protein and iso-energy equal. Experimental diets (Table 1 and 2) were balanced according to digestible amino acid contents of feed, following Rostagno et al. (2017), and according to nutritional requirements recommended by Silva \& Costa (2009), except digestible lysine at sub-optimal level, corresponding to minus $10 \%$ of the recommended level. Amino acid ratios with lysine, proposed by Silva \& Costa (2009) were maintained, except for methionine + cysteine and digestible threonine. Ratio for methionine + cysteine: lysine followed Castro (2014) at 0.81 and 0.68 . Further, 3\% for each amino acids requirements were added to safeguard lack of deficiency, except lysine and digestible threonine. 
Table 1. Calculated and percentual compositions of the experimentals diets, in a natural matter, for female meat-type quail of 21 to 28 days of old

\begin{tabular}{lccccc}
\hline Ingredients & \multicolumn{5}{c}{ Digestible Threo: Lys ratios } \\
\cline { 2 - 6 } & 0.66 & 0.71 & 0.76 & 0.81 & 0.86 \\
\hline Basic Diet $(1)$ & 99.395 & 99.395 & 99.395 & 99.395 & 99.395 \\
L-Threonine $(98,5 \%)$ & 0.000 & 0.046 & 0.093 & 0.140 & 0.187 \\
L-Glutamic $(99,4 \%)$ & 0.500 & 0.435 & 0.370 & 0.306 & 0.241 \\
Starch & 0.100 & 0.117 & 0.135 & 0.153 & 0.171 \\
Total & 100.00 & 100.00 & 100.00 & 100.00 & 100.00 \\
\hline Calculated composition & & & & & \\
\hline Metabolizable energy (kcal/kg) & 3.050 & 3.050 & 3.050 & 3.050 & 3.050 \\
Crude protein (\%) & 19.073 & 19.073 & 19.073 & 19.073 & 19.073 \\
Calcium (\%) & 0.700 & 0.700 & 0.700 & 0.700 & 0.700 \\
Available phosphorus (\%) & 0.270 & 0.270 & 0.270 & 0.270 & 0.270 \\
\hline Digestibles amino acids (\%) & & & & & \\
\hline Lysine & 0.920 & 0.920 & 0.920 & 0.920 & 0.920 \\
Methionine + cysteine & 0.753 & 0.753 & 0.753 & 0.753 & 0.753 \\
Threonine & 0.607 & 0.653 & 0.699 & 0.745 & 0.791 \\
Tryptophan & 0.177 & 0.177 & 0.177 & 0.177 & 0.177 \\
Arginine & 1.383 & 1.383 & 1.383 & 1.383 & 1.383 \\
\hline
\end{tabular}

${ }^{1}$ per kg of product: Cobalt: $2 \mathrm{~g}$, copper: $20 \mathrm{~g}$, iron: $100 \mathrm{~g}$, iodine: $2 \mathrm{~g}$, manganese: $160 \mathrm{~g}$, zinc: $100 \mathrm{~g}$, vehicle q.s.p.: $1000 \mathrm{~g}$; ${ }^{2}$ per kg of product: Folic acid: $700 \mathrm{mg}$, pantothenic acid: $10.000 \mathrm{mg}$, BHT 1000mg, biotin: $20 \mathrm{mg}$, niacin: $30 \mathrm{mg}$, vit. A: 6.000 .000 U.I., vit B1: $1.200 \mathrm{mg}$, vit. B12: $7.000 \mathrm{mcg}$, vit B2: $4.000 \mathrm{mg}$, vit B6: $2.400 \mathrm{mg}$, vit D3: 1.200 .000 U.I., vit. E: 12.000 U.I., vit. K3: $1.2000 \mathrm{mg}$, vehicle q.s.p.: $1.000 \mathrm{~g}$. 
Table 2. Calculated and percentual compositions of the experimentals diets, in a natural matter, for female meat-type quail of 28 a 35 days old

\begin{tabular}{lccccc}
\hline Ingredients & \multicolumn{5}{c}{ Digestible Threo: Lys ratios } \\
\cline { 2 - 6 } & 0.66 & 0.71 & 0.76 & 0.81 & 0.86 \\
\hline Basic Diet ${ }^{(1)}$ & 99.395 & 99.395 & 99.395 & 99.395 & 99.395 \\
L-Threonine (98,5\%) & 0.000 & 0.047 & 0.094 & 0.141 & 0.187 \\
L-Glutamic (99,4\%) & 0.500 & 0.435 & 0.371 & 0.306 & 0.241 \\
Starch & 0.100 & 0.117 & 0.135 & 0.153 & 0.171 \\
Total & 100.00 & 100.00 & 100.00 & 100.00 & 100.00 \\
\hline Calculated composition & & & & & \\
\hline Metabolizable energy (kcal/kg) & 3.050 & 3.050 & 3.050 & 3.050 & 3.050 \\
Crude protein (\%) & 19.000 & 19.000 & 19.000 & 19.000 & 19.000 \\
Calcium (\%) & 0.700 & 0.700 & 0.700 & 0.700 & 0.700 \\
Available phosphorus (\%) & 0.270 & 0.270 & 0.270 & 0.270 & 0.270 \\
\hline Digestibles amino acids (\%) & & & & & \\
\hline Lysine & 0.920 & 0.920 & 0.920 & 0.920 & 0.920 \\
Methionine + cysteine & 0.644 & 0.644 & 0.644 & 0.644 & 0.644 \\
Threonine & 0.607 & 0.653 & 0.699 & 0.745 & 0.791 \\
Tryptophan & 0.177 & 0.177 & 0.177 & 0.177 & 0.177 \\
Arginine & 1.383 & 1.383 & 1.383 & 1.383 & 1.383 \\
\hline
\end{tabular}

${ }^{1}$ per kg of product: Cobalt: $2 \mathrm{~g}$, copper: $20 \mathrm{~g}$, iron: $100 \mathrm{~g}$, iodine: $2 \mathrm{~g}$, manganese: $160 \mathrm{~g}$, zinc: $100 \mathrm{~g}$, vehicle q.s.p.: $1000 \mathrm{~g}$; ${ }^{2}$ per $\mathrm{kg}$ of product: Folic acid: $700 \mathrm{mg}$, pantothenic acid: $10.000 \mathrm{mg}$, BHT 1000mg, biotin: $20 \mathrm{mg}$, niacin: $30 \mathrm{mg}$, vit. A: 6.000 .000 U.I., vit B1: $1.200 \mathrm{mg}$, vit. B12: $7.000 \mathrm{mcg}$, vit B2: $4.000 \mathrm{mg}$, vit B6: $2.400 \mathrm{mg}$, vit D3: 1.200 .000 U.I., vit. E: 12.000 U.I., vit. K3: $1.2000 \mathrm{mg}$, vehicle q.s.p.: $1.000 \mathrm{~g}$.

Performance variables evaluated in the first and second assays were feed intake (g/fowl), weight gain ( $\mathrm{g} /$ fowl) and feed conversion $(\mathrm{g} / \mathrm{g})$. Feed intake was corrected by mortality data, if it occurred. Evaluation of the second assay comprised characteristics of carcass and cuts (breast and thigh + drumstick) yields, weight of feathers and chemical composition of carcass in dry matter, crude protein and ether extract. Four 35day-old quails from each experimental unit were sampled randomly and killed. After a 6-h fast, two quails of each split were weighed one by one and tagged. Insensitiveness occurred by sectioning of spine medulla, followed by bleeding and temperature-controlled scalding at $53-55^{\circ} \mathrm{C}$, during $20-40$ seconds, with removal of feather by electric peeling machine. Carcasses were eviscerated and placed in a pre-chiller bath at $4^{\circ} \mathrm{C}$, for 30 minutes. Cuts were done to provide carcass weight (without feet and head) and weight of cuts. Body weight (g), yield (\%) of carcass and best cuts (breast and thigh + drumstick) were evaluated. After weighing carcasses, yield was obtained and compared to post-fast live weight by equation: carcass yield $(\%)=$ [(weight of carcass/live weight) x 100]. Yield (\%) of cuts was given as a function of eviscerated carcass weight, without feet and head, by equation: cut yield (\%) 
$=[$ (weight of cut $/$ weight of carcass $) \mathrm{x}$ $100]$.

Two sampled poultry per experimental unit were used for feather weight after the insensitiveness stage. After quails were killed, scalding and manual feather peeling were undertaken. Quails were then dried by tissue paper and weighed again. Difference of quail weight with feathers minus weight without provided feather weight. The same quails were used to determine the chemical composition of carcass at dry matter, crude protein and ether extract. Carcasses were eviscerated manually, washed, frozen $\left(-18^{\circ} \mathrm{C}\right)$ and packed in tagged plastic bags. Carcasses (with feet and head) were ground in an industrial meat grinding machine, homogenized, weighed and kept in an forced-air oven at $55^{\circ} \mathrm{C}$ for $96 \mathrm{~h}$ for pre-drying. Pre-dried carcasses were ground in a ball-type grinder and the carcass chemical composition analyzed following methodology by Silva \& Queiroz (2004). Nitrogen balance was determined for the 28 to 35-day period. Total retrieval of excreta was undertaken between the $31^{\text {st }}$ and $35^{\text {th }}$ day of age, with 3 days for adaptation to diets and cages $\left(28^{\text {th }}\right.$ to $30^{\text {th }}$ day) and five days for collection. Excreta (without feathers and diet) were collected twice a day, conditioned in tagged plastic bags and frozen $\left(-18^{\circ} \mathrm{C}\right)$ for later analyses. Excreta were homogenized and weighed within their respective splits and then a $100 \mathrm{~g}$ sample was pre-died in a forced-air buffer at $55^{\circ} \mathrm{C}$ for $36 \mathrm{~h}$. Samples were ground in knife-grinder with $0.01 \mathrm{~cm}$ sieve. Nitrogen retention was calculated by the difference between Nitrogen consumption and Nitrogen excretion. Diet and excretion analyses were done following Silva \& Queiroz (2004), for dry matter and total nitrogen.

Results of variables underwent variance and regression analyses taking into consideration digestible Threo: Lys ratios as independent variable, according to simple and quadratic polynomial regression models, at 5\% probability. Sum of squares of deviations and coefficients of determination were taken into account to verify adjustment of models $\left(\mathrm{R}^{2}=\mathrm{SQ}\right.$ regression/ $\mathrm{SQ}$ treatments).

\section{RESULTS AND DISCUSSION}

Mean temperatures were maximum $22^{\circ}$ $\mathrm{C}$ and minimum $19^{\circ} \mathrm{C}$ for the period 21 to 28 days of age and $20^{\circ} \mathrm{C}$ maximum and $18^{\circ} \mathrm{C}$ minimum for 28 to 35 days of age.

Quails' feed conversion improved $(\mathrm{P}<0.05)$ with increase of digestible Threo: Lys ratio of diets during the period 21 to 28 days old. However, there was no effect $(\mathrm{P}>0.05)$ on feed intake and weight gain of quails (Table 3 ). 
Table 3. Average \pm standard error of feed intake (FI), weigth gain (WG) and feed conversion (FC) of female meat-type quails fed with digestible Threo: Lys ratios

\begin{tabular}{|c|c|c|c|c|c|c|c|}
\hline \multirow{2}{*}{ Item } & \multicolumn{5}{|c|}{ Digestible Threo: Lys ratios (21 to 28 days old) } & \multirow{2}{*}{$\mathrm{VC}^{1}(\%)$} & \multirow{2}{*}{ P-value } \\
\hline & 0.66 & 0.71 & 0.76 & 0.81 & 0.86 & & \\
\hline FI $(g)$ & $\begin{array}{c}171.65 \\
\pm 2.23\end{array}$ & $\begin{array}{c}173.18 \\
\pm 1.28\end{array}$ & $\begin{array}{c}171.48 \\
\pm 2.07\end{array}$ & $\begin{array}{c}171.87 \pm 2 \\
.70\end{array}$ & $\begin{array}{c}168.69 \pm \\
2.63\end{array}$ & 3.61 & 0.3033 \\
\hline WG $(\mathrm{g})$ & $\begin{array}{c}55.50 \pm \\
1.42\end{array}$ & $\begin{array}{c}57.35 \pm \\
0.61\end{array}$ & $\begin{array}{c}55.82 \pm \\
1.42\end{array}$ & $\begin{array}{c}55.83 \pm 1 \\
56\end{array}$ & $\begin{array}{c}56.97 \pm 1 \\
.00\end{array}$ & 6.19 & 0.7173 \\
\hline $\mathrm{FC}^{2}(\mathrm{~g} / \mathrm{g})$ & $\begin{array}{c}3.10 \pm 0 . \\
05\end{array}$ & $\begin{array}{c}3.02 \pm 0 \\
03\end{array}$ & $\begin{array}{c}3.08 \pm 0 . \\
05\end{array}$ & $\begin{array}{c}3.02 \pm 0.0 \\
4\end{array}$ & $\begin{array}{c}2.96 \pm 0 . \\
03\end{array}$ & 3.73 & 0.0353 \\
\hline \multirow{2}{*}{ Item } & \multicolumn{5}{|c|}{ Digestible Threo: Lys ratios (28 to 35 days old) } & & \\
\hline & 0.66 & 0.71 & 0.76 & 0.81 & 0.86 & & ate \\
\hline $\mathrm{FI}^{3}(\mathrm{~g})$ & $\begin{array}{c}254.16 \\
\pm 3.27\end{array}$ & $\begin{array}{c}265.35 \\
\pm 2.84\end{array}$ & $\begin{array}{c}263.12 \\
\pm 3.19\end{array}$ & $\begin{array}{c}265.10 \pm 1 \\
.26\end{array}$ & $\begin{array}{c}265.18 \pm \\
2.99\end{array}$ & 3.16 & 0.0254 \\
\hline WG (g) & $\begin{array}{c}41.47 \pm \\
2.02\end{array}$ & $\begin{array}{c}42.96 \pm \\
1.20\end{array}$ & $\begin{array}{c}41.40 \pm \\
1.93\end{array}$ & $\begin{array}{c}41.43 \pm 1 \\
59\end{array}$ & $\begin{array}{c}43.82 \pm 1 \\
.70\end{array}$ & 10.68 & 0.5432 \\
\hline $\mathrm{FC}(\mathrm{g} / \mathrm{g})$ & $\begin{array}{c}5.87 \pm 0 . \\
05\end{array}$ & $\begin{array}{c}5.83 \pm 0 . \\
03\end{array}$ & $\begin{array}{c}5.84 \pm 0 . \\
05\end{array}$ & $\begin{array}{c}5.87 \pm 0.0 \\
4\end{array}$ & $\begin{array}{c}5.82 \pm 0 . \\
04\end{array}$ & 1.88 & 0.5553 \\
\hline
\end{tabular}

${ }^{1} \mathrm{VC}(\%)=$ variation coefficient; ${ }^{2} \mathrm{FC}=3,46021-0,55756 \mathrm{X}\left(\mathrm{R}^{2}=0,64\right) ;{ }^{3} \mathrm{FI}=229,52712+$ $43,48446 \mathrm{X}\left(\mathrm{R}^{2}=0,51\right)$.

According to Ospina-Rojas et al. (2013), increase in threonine in broiler chickens improves feed conversion due to increase in mucin synthesis, with greater protection and development of mucous, favoring more effective absorption of nutrients. Mucous is formed by $95 \%$ water and approximately $5 \%$ mucin which consist of high molecular weight glycoproteins. This favorable threonine effect may have occurred with the quails due to improvement of feed conversion. Qaisrani et al. (2018) report that mucin is mainly formed by threonine, serine and proline, with the former having the highest concentration (28 - 40\%). Further, Chen et al. (2017) observed that increasing inclusion of total threonine in the diet of broiler chickens increases villi height, height of villi / crypt depth and decrease in crypt depth, in the jejunum, by $18.3 ; 33.0$ and $12.5 \%$, respectively. Machado et al. (2018) also reported an increase in the ratio height of villi / crypt depth of slow growth broiler chickens as ratio digestible Threo: Lys increased in the diets. Association of the above factors may better explain the quail's feed improvement during this phase. Similarly, Baylan et al. (2006) observed feed improvement of Japanese quails in the 1 to 35-day-old phase, with an increase of threonine in the diet, and recommended 0.78 as digestible ThreoLys ratio. However, Umigi et al. (2012) and Ton et al. (2013) failed to report any effect on feed conversion, feed intake and weight gain of Japanese quails with regard to egg production and meat-type quails, respectively, due to increase of digestible Threo-Lys ratios in corn and soybean meal-based diets.

There was an increasing linear effect $(\mathrm{P}<0.05)$ on the feed intake by quails when an increase of digestible Threo: Lys ratio occurred for the 28 to 35 days old phase. However, there was no effect $(\mathrm{P}>0.05)$ on feed conversion and weight gain of quails (Table 3 ). High variation coefficient for weight gain may have 
jeopardized the significant effect expression of the variable.

Debnath et al. (2019) reported a linear increase of feed intake by 1 to 21-day old broiler chickens fed on increasing levels of digestible threonine. According to these authors, higher digestible threonine levels in the diet may have activated appetite regulation mechanisms or may have altered plasmatic profile which, in its turn, is sensitive to variations in amino acid concentrations. Further, Azzam \& El-Gogary (2015) state that threonine may trigger the production of triiodothyronine (T3) and thyroxine (T4), and, consequently, it may stimulate intake.

Several authors (UMIGI et al. 2012; LIMA et al., 2013; TON et al., 2013) failed to perceive any effect for increase in digestible threonine levels and digestible Threo-Lys ratios in the diet of Japanese quails and meat-type quails on animal performance variables. Several factors may justify the non-occurrence, such as lack of sanitary challenge in poultry breeding, adequate rate of crude protein in the diet and metabolizable energy level and the feed equilibrium in the formulas. Levels of crude protein and metabolizable energy employed in current assay are different from those used by the above-mentioned authors and may thus explain variations in results. Further, difference in genotypes, gender, development stage, quality and balance of ingredients used in the formulas also interfere in nutritional demands of several amino acids (EBLING et al., 2013) and may foreground different results among research works.

Increase in yield carcass of 35-day-old meat-type quails has also been reported $(\mathrm{P}<0.05)$, due to increasing digestible Threo-Lys ratios in diets (Table 4). However, no significant effect $(\mathrm{P}>0.05)$ has been detected on body weight, breast yield, thigh + drumstick yield and weight of feathers.

Table 4. Average \pm standard error of body weight (BW), carcass yield (CY), breast yield (BY), thigh + drumstick yield (TWY) and weight of feather (WF) of female meat-type quails fed with digestible Threo: Lys ratios at 35 days old

\begin{tabular}{|c|c|c|c|c|c|c|c|}
\hline \multirow{2}{*}{ Item } & \multicolumn{5}{|c|}{ Digestible Threo: Lys ratios (\%) } & \multirow{2}{*}{$\mathrm{VC}^{1}(\%)$} & \multirow{2}{*}{ P-value } \\
\hline & 0.66 & 0.71 & 0.76 & 0.81 & 0.86 & & \\
\hline BW (g) & 269.68 & 269.85 & 270.98 & $263.04 \pm 2$ & $272.75 \pm$ & 3.42 & 0.715 \\
\hline & \pm 3.29 & \pm 3.38 & \pm 2.71 & .37 & 3.76 & & \\
\hline${ }^{2} \mathrm{CY}(\%)$ & $71.19 \pm$ & $70.84 \pm$ & $72.01 \pm$ & $72.16 \pm 0$ & $72.93 \pm 0$ & 1.81 & 0.002 \\
\hline BY (\%) & 0.36 & 0.35 & 0.42 & $\begin{array}{c}73 \\
45+0\end{array}$ & $\begin{array}{c}.35 \\
4306+0\end{array}$ & 403 & 0081 \\
\hline & $\begin{array}{c}45.02 \pm \\
0.62\end{array}$ & $\begin{array}{c}44.14 \pm \\
0.77\end{array}$ & $\begin{array}{l}4.50 \pm \\
0.46\end{array}$ & 73 & .30 & & \\
\hline TWY (\%) & $\begin{array}{c}23.65 \pm \\
0.20\end{array}$ & $\begin{array}{c}23.43 \pm \\
0.26\end{array}$ & $\begin{array}{c}23.51 \pm \\
0.35\end{array}$ & $\begin{array}{c}23.72 \pm 0 . \\
29\end{array}$ & $\begin{array}{c}23.65 \pm 0 \\
.27\end{array}$ & 3.17 & 0.741 \\
\hline WF $(g)$ & $\begin{array}{c}13.42 \pm \\
0.74\end{array}$ & $\begin{array}{c}14.02 \pm \\
0.82\end{array}$ & $\begin{array}{c}13.93 \pm \\
0.86\end{array}$ & $\begin{array}{c}13.71 \pm 0 . \\
32\end{array}$ & $\begin{array}{c}13.99 \pm 0 \\
.69\end{array}$ & 14.23 & 0.703 \\
\hline
\end{tabular}

${ }^{1} \mathrm{VC}(\%)=$ variation coefficient; ${ }^{2} \mathrm{CY}=64,54507+9,57758 \mathrm{X}\left(\mathrm{R}^{2}=0,84\right)$

Improvement in carcass yield may be due to the linear effect in feed intake during this phase, enhancing greater intake of threonine and other limiting amino acids, such as methionine and lysine directly linked to carcass yield. European quails require a greater amount of lysine when compared to the diet's protein contents since they have a higher growth rate, especially breast muscles. Lysine is greatly employed for body protein synthesis (Silva et al., 2012). 
Al-Hayani (2017) detected an increase in feed intake, in plasmatic concentrations of total protein and $\mathrm{GH}$ of 35-day-old broilers due to increase of threonine inclusion in the diet. Debnath et al. (2019) also confirmed increase in feed intake associated with increase of total serum protein in 21-day-old broilers due to increase of digestible Threo-Lys ratios in the diet. Association of these factors may indicate the causes of linear improvement in carcass yield. However, several studies (BAYLAN et al., 2006; UMIGI et al., 2012; TON et al., 2013) reported lack of effects on quail carcass due to increase in digestible Threo: Lys ratios.

No significant effect $(\mathrm{P}>0.05)$ of digestible Threo: Lys ratios was detected on dry matter, crude protein and ether extract rates of 35-day-old quail carcasses (Table 5). However, there was a decreasing linear effect $(\mathrm{P}<0.05)$ due to increase in Threo: Lys ratios under analysis on the nitrogen balance of quails. In fact, it was negative for all ratios studied.

Table 5. Average \pm standard error of content in carcass of dry matter (DM), crude protein (CP) and ether extract (EE) and nitrogen balance of female meat-type quails fed with digestible Threo: Lys ratios at 35 days old

\begin{tabular}{|c|c|c|c|c|c|c|c|}
\hline \multirow{2}{*}{ Item } & \multicolumn{5}{|c|}{ Digestible Threo: Lys ratios (\%) } & \multirow{2}{*}{$\begin{array}{l}\mathrm{VC}^{1} \\
(\%)\end{array}$} & \multirow{2}{*}{$\begin{array}{c}\text { P- } \\
\text { value }\end{array}$} \\
\hline & 0.66 & 0.71 & 0.76 & 0.81 & 0.86 & & \\
\hline $\mathrm{DM}(\%)$ & $\begin{array}{c}30.65 \pm 0 . \\
33\end{array}$ & $\begin{array}{c}31.08 \pm 0.5 \\
1\end{array}$ & $\begin{array}{c}31.62 \pm 0.4 \\
2\end{array}$ & $\begin{array}{c}30.98 \pm 0.4 \\
8\end{array}$ & $\begin{array}{c}30.78 \pm 0.4 \\
0\end{array}$ & 3.89 & 0.288 \\
\hline $\mathrm{CP}(\%)$ & $\begin{array}{c}59.63 \pm 0 \\
75\end{array}$ & $\begin{array}{c}59.96 \pm 0.7 \\
7\end{array}$ & $\begin{array}{c}59.30 \pm 0.8 \\
3\end{array}$ & $\begin{array}{c}59.44 \pm 0.7 \\
7\end{array}$ & $\begin{array}{c}60.17 \pm 0.4 \\
1\end{array}$ & 3.31 & 0.803 \\
\hline $\mathrm{EE}(\%)$ & $\begin{array}{c}26.01 \pm 1 . \\
31\end{array}$ & $\begin{array}{c}26.33 \pm 0.8 \\
3\end{array}$ & $\begin{array}{c}28.51 \pm 1.6 \\
2\end{array}$ & $\begin{array}{c}26.87 \pm 1.5 \\
9\end{array}$ & $\begin{array}{c}28.07 \pm 1.1 \\
5\end{array}$ & $\begin{array}{c}13.6 \\
0\end{array}$ & 0.268 \\
\hline${ }^{2} \mathrm{NB}$ & $\begin{array}{c}- \\
0.11 \pm 0.0 \\
2\end{array}$ & $\begin{array}{c}- \\
0.10 \pm 0.03\end{array}$ & $\stackrel{-}{-} 0.14 \pm 0.03$ & $\stackrel{-}{-} 0.17 \pm 0.04$ & $\begin{array}{c}- \\
0.20 \pm 0.04\end{array}$ & $\begin{array}{c}- \\
62.6 \\
9\end{array}$ & 0.018 \\
\hline
\end{tabular}

${ }^{1} \mathrm{VC}(\%)=$ variation coefficient; ${ }^{2} \mathrm{NB}=0,24434-0,51363 \mathrm{X}\left(\mathrm{R}^{2}=0,90\right)$

According to Reginatto et al. (2000), threonine levels in the diet did not affect the composition of the carcass of broiler chickens, regardless of crude protein levels, metabolized energy and crude protein: metabolizable energy ratio in the diet. Ton et al. (2013) also reported a lack of effect by increase of digestible Threo-Lys ratios in the diet of 35-dayold meat-type quails on the parameters of carcass composition.

Lee et al. (2007) reported that after being absorbed, threonine goes to form muscular protein, mucin and immuneglobulin synthesis. Since it is a glycogenic amino acid, its catabolism has two pathways for energy formation: ketogenesis and glycogenesis. Consequently, threonine's carbon skeleton produces pyruvate, propionate, acetyl coA, $\mathrm{CO}_{2}$ and $\mathrm{H}_{2} \mathrm{O}$ for the production of energy, whilst it is a glycine and serine precursor, incorporating Nitrogen in the molecule of uric acid and forming non-protein compounds (KIDD \& KERR, 1997; DEBNATH et al., 2019). Consequently, increase in threonine levels may increase protein synthesis at optimal levels of inclusion and ether extract at high levels, 
with subsequent changes in the rates of carcass's dry matter. The above has not been observed in current study.

Castro et al. (2016) also reported negative results in nitrogen balance as ratios between methionine + cysteine: digestible lysine in the diet of 22 to $35-$ day-old meat-type quails increases. According to these authors, negative rates of nitrogen balance may be explained by the poultry's old age since most nitrogen retention (positive rates) occurs in periods with high protein deposition rates and organ development. The latter are more enhanced in the early phases of life. According to McLeod (1997), incorporation of an amino acid within a protein chain costs 4 mols, whilst the removal of such a cost requires between 6 and $18 \mathrm{mols} \mathrm{ATP} / \mathrm{g}$ of $\mathrm{N}$. However, the metabolic cost for the excretion of surplus of compounds from threonine catabolism did not affect net energy for carcass performance and yield. The latter evidences adequate balance of amino acids, energy and other nutrients of the diet given to the quails.

Recommendations of the tables for digestible Threo: Lys by Silva \& Costa (2009) for phases 22 to 42-day-old meattype quails, and those by Rostagno et al. (2017) for the 15 to 35 day-old phase for laying quails are respectively 0.76 and 0.71. Different digestible Threo: Lys ratios for meat-type quails were provided by Baylan et al. (2006) and by Ton et al. (2013), namely, 0.78 and 0.54 , respectively. However, it should be underscored that experimental conditions (gender, age, strain, diet, environmental conditions and sanitary challenge) and data statistical mechanisms may affect the recommended levels given in the different research works. Reis et al. (2016) report that, for the same characteristic evaluated (intestine morphometry), different levels of digestible threonine may be estimated, consequently revealing the existence of different effects which depend on the different section of the small intestine under analysis.

Further studies are needed to clarify the different digestible threonine-lysine ratios in the diets of meat-type quails. Studies with amino acid ratios above those evaluated in current study are recommended, coupled to other variables which should be investigated to better determine ratios such as intestine health.

Considering evaluated levels during periods 21 to 28 days old and 28 to 35 days old of female meat-type quails, the digestible Threo-Lys ratio of 0.86 may be recommended as the optimal level for feed conversion and yield of quail carcass.

\section{ACKNOWLEDGMENTS}

This study was financed in part by the FAPEMIG (Fundação de Amparo à Pesquisa do Estado de Minas Gerais), process APQ01403/13 and Coordenação de Aperfeiçoamento de Pessoal de Nivel Superior - Brasil (CAPES) - Finance Code 001. The authors would like to thank the company Ajinomoto Ltda by donation of amino acids.

\section{REFERENCES}

AL-HAYANI, W.K.A. Effect of threonine supplementation on broiler chicken productivity traits.

International Journal of Poultry

Science, v.16, n.4, p. 160-168, 2017. 
AZZAM, M.M.M.; EL-GOGARY, M.R. Effects of dietary threonine levels and stocking density on the performance, metabolic status and immunity of broiler chickens. Asian Journal of Animal and Veterinary Advances, v.10, n.5, p.215-225, 2015.

BAYLAN, M.; CANOGULLARI, S.; AYASAN, T.; SAHIN, A. Dietary threonine supplementation for improving growth performance and edible carcass parts in Japanese quails, Coturnix coturnix Japonica. International Journal of Poultry Science, v.5, n.7, p.635-638, 2006.

CASTRO, M.R.; PINHEIRO, S.R.F.; LIMA, H.J.D.; PIRES, A.V.; VIEIRA, D.J.; ABREU, L.R.A.; MOTA, L.F.M.; OLIVEIRA, R.G. Relações metionina + cistina digestíveis para codornas de corte machos em fase de terminação. Revista Brasileira de Saúde e Produção Animal, v.17, n.2, p.162173, 2016.

CASTRO, M.R. Relações metionina + cistina: lisina digestíveis para codornas de corte. 2014. 54 p. Dissertação (Mestrado) - Programa de Pós-Graduação em Zootecnia, Universidade Federal dos Vales do Jequitinhonha e Mucuri, Diamantina, 2014

CHEN, Y.P.; CHENG, Y.F.; LI, X.H.; YANG, W.L.; WEN, C.; ZHUANG, S.; ZHOU, Y.M. Effects of threonine supplementation on the growth performance, immunity, oxidative status, intestinal integrity, and barrier function of broilers at the early age. Poultry Science, v.96, p.405-413, 2017.
CORZO, A.; KIDD, M.T.; DOZIER III, W.A.; PHARR, G.T.; KOUTSOS, E.A. Dietary threonine needs for growth and immunity of broilers raised under different litter conditions. Journal Applied of Poultry Research, v.16, p.574-582, 2007.

DEBNATH, B.C.; BISWAS, P.; ROY, $B$. The effects of supplemental threonine on performance, carcass characteristics, immune response and gut health of broilers in subtropics during pre-starter and starter period. Journal of Animal Physiology and Animal Nutrition, v.103, n.1, p.29-40, 2019.

EBLING, P.D.; RIBEIRO, A.M.L.; TREVIZAN, L.; SILVA, I.C.M.; KESSLER, A.M.; RUBIN, L.L. Effect of different dietary concentrations of amino acids on the performance of two different broiler strains. Revista Brasileira de Ciência Avícola, v.15, n.4, p.339-346, 2013.

KIDD, M.T.; KERR, B.J. Threonine responses in commercial broiler at 30 to 42 days. Journal of Applied Poultry Research, v.6, p.362-367, 1997.

LEE K.H.; PARK, J.H.; KIM, T.Y.; KIM, H.U.; LEE, S.Y. Systems metabolic engineering of Escherichia coli for L-threonine production.

Molecular Systems Biology, v.3, n.149, p. 1-9, 2007.

LIMA, M.R.; COSTA, F.G.P.; GUERRA, R.R.; SILVA, J.H.V.; RABELLO, C.B.V.; MIGLINO, M.A.; LOBATO, G.B.V.; SENA NETTO, S.B.S.; DANTAS, L.S. Threonine: lysine ratio for Japanese quail hen diets. 
Journal Applied Poultry Research, v.22, p.260-268, 2013.

MACHADO, N.J.B.; LIMA, C.A.R.; BRASIL, R.J.M.; QUARESMA, D.V.; DILELIS, F.; SILVA, A.P.P.;

CURVELLO, F.A. Digestible threonine for slow-growing broilers: performance, carcass characteristics, intestinal mucin, and duodenal morphometry. Revista Brasileira de Zootecnia, v. 47, p. 1-9, 2018.

Mc LEOD, M. Effects of amino acid balance and energy: protein ratio on energy and nitrogen metabolism in male broiler chicken. British Poultry Science, v.38, p.405-411, 1997.

OSPINA-ROJAS, I.C.; MURAKAMI, A.E.; MOREIRA, I.; PICOLI, K.P.; RODRIGUEIRO, R.J.; FURLAN, A.C. Dietary glycine+serine responses of male broilers given low protein diets with different concentrations of threonine. British Poultry Science, v. 54, n. 4, p. 486-493, 2013.

QAISRANI, S.N.; AHMED, I.; ZAM, F.; BIBI, F.; SAIMA, T.N.P.; AZAM, F. Threonine in broiler diets: an updated review. Annals of Animal Science, v. 18, n.3, p. 659-674, 2018.

REGINATTO, M.F.; RIBEIRO, A.M.L.; PENZ JR, A.M.; KESSLER, A.M.; KRABBE, E.L. Suplementação de treonina em dietas de frangos de corte, variando a energia e as relações energia: proteína. Revista Brasileira de Ciência Avícola, v.2, n.3, p.239-247, 2000.

REIS, J.S.; DIONELLO, N.J.L.; NUNES, A.P.; LOPES, D.C.N.; GOTUZZO, A.G.; TYSKA, D.U.;
RUTZ, F. Morfometria intestinal em codornas de corte alimentadas com treonina digestível. Arquivo Brasileiro de Medicina Veterinária e Zootecnia, v.68, n.4, p.983-990, 2016.

ROSTAGNO, H.S.; ALBINO, L.F.T.; HANNAS, M.I., DONZELE, J.L., SAKOMURA, N.K., PERAZZO, F.G., SARAIVA, A., TEIXEIRA, M.L., RODRIGUES, P.B., OLIVEIRA, R.F., BARRETO, S.L.T., BRITO, C.O.

Tabelas Brasileiras para Aves e Suínos: Composição de Alimentos e Exigências Nutricionais. 4.ed. VIÇOSA: UFV, Departamento de Zootecnia, 2017. 488p.

SILVA, D.J.; QUEIROZ, A.C.D. Análises de alimentos: métodos químicos e biológicos. 3.ed. Viçosa, MG: UFV, 2004. 235p.

SILVA, J.H.V.; COSTA, F.G.P. Tabelas para codornas japonesas $\mathrm{e}$ européias. 3.ed. Jaboticabal, SP: Funep, 2009. 107p.

SILVA, E.L.; SILVA, J.H.V.; JORDÃO FILHO, J.; RIBEIRO, M.L.G.; COSTA, F.G.P.; RODRIGUES, P.B. Redução dos níveis de proteína e suplementação aminoacídica em rações para codornas européias (Coturnix coturnix coturnix). Revista Brasileira de Zootecnia, v.35, n.3, p.822-829, 2006.

SILVA, J.H.H.; JORDÃO FILHO, J.; COSTA, F.G.P.; LACERDA, P.B.; VARGAS, D.G.V.; LIMA, M.R. Exigências nutricionais de codornas. Revista Brasileira de Saúde e Produção Animal, v.13, n.3, p.775790, 2012. 
TON, A.P.S.; FURLAN, A.C.;

MARTINS, E.N.; BATISTA, E.;

PASQUETTI, T.J.; SCHERER, C.;

IWAHASHI, A.S.; QUADROS, T.C.O.

Nutritional requirements of digestible

threonine for growing meat-type quails.

Revista Brasileira de Zootecnia, v.42,

n.7, p.504-510, 2013.

UMIGI, R.T.; BARRETO, S.L.T.;

REIS, R.S.; MESQUITA FILHO, R.M.;

ARAÚJO, M.S. Níveis de treonina

digestível para codorna japonesa na fase

de produção. Arquivo Brasileiro de

Medicina Veterinária e Zootecnia,

v.64, n.3, p.658-664, 2012. 